\title{
Research on the Relationship between Classroom Climate and Learning Motivation of College Students: Mediating Effect of Self-efficacy
}

\author{
Chih Huang \\ School of Business \\ Beijing Institute of Technology, Zhuhai \\ Zhuhai, China
}

\author{
Yishan Shen \\ School of Business \\ Beijing Institute of Technology, Zhuhai \\ Zhuhai, China
}

\author{
Sisi Huang \\ School of Business \\ Beijing Institute of Technology, Zhuhai \\ Zhuhai, China
}

\begin{abstract}
The main purpose of this study is to explore the impact of classroom climate on learning motivation and to verify the mediating effect of self-efficacy on classroom climate and learning motivation. In this study, the author investigated the students in the college of Business of $B$ University. And the results showed that classroom climate (teacher support, classmate relationship) had significant and positive impact on learning motivation (learning interest, self-development, social relations, external expectations). In addition, self-efficacy has complete mediating effect on the relationship between students' relationship and learning motivation. There is some mediation effect on the relationship between teacher support and learning motivation.
\end{abstract}

Keywords-classroom climate; learning motivation; selfefficacy

\section{INTRODUCTION}

For many teachers, it is a challenging task to maintain or enhance students' learning motivation (Denzine \& Brown, 2014). Hakan \& Munire (2014) pointed out that motivation had significant impact on learners' attitudes and learning behaviors. For example, students with high learning motivation would be more willing to have the learning. They would be active in class, enjoy high spirits and be happy and fulfilled from learning activities. However, without the learning motivation, students would learn very little from the class. Also, they would feel painful and frustrated in the learning process. Therefore, the intensity of learning motivation will affect the degree of students' efforts and perseverance. And it plays an important role in learning behavior.

Classroom is an important area for students to have the learning activities. According to the studies on motivation theory and students' learning, classroom climate is closely related to the learning environment. And it has dominant effect on students' learning motivation (Brophy, 1998;
Pintrich \& Schunk, 1996). It is also the main determinant for classroom behavior and learning (Djigic \& Stojiljkovic, 2011). Adelman \& Taylor (2005) pointed out that the impact of classroom climate on students' learning motivation may be positive. However, it may also form an obstacle. Among them, the classroom atmosphere formed by the interaction between teachers and peers has a decisive influence. Therefore, with the interaction between teachers and peers, it should create the classroom climate with supportive and cooperative learning. And then, it could stimulate students' learning motivation. The learning objectives are very important issues in the teaching process. Second, there is a possibility that the objective of motivation may have internal or external differences due to the different internal and external personal rewards. In the previous researches, it is rare in this term. Therefore, this study will take this motivation as the basis to explore the impact of classroom climate on learning motivation of different orientations.

Social learning theory considers individuals to have a cognitive self-regulation mechanism. And perceived selfefficacy is the core element of the self-regulation mechanism that affects individual motivation and behavior (Bandura, 1982). Social learning theory points out those individuals do not passively accept the stimulus of environmental and behavioral feedback. It would have interaction with the outside world through their internal psychological mechanisms. Torkzadeh \& Van Dyke (2001) also points out that self-efficacy is also dynamic construct. And individuals' perceptions of their effectiveness would change with new information and experience gained.

Accordingly, this study argues that in the learning process, individuals would have sense-making of various clues or events provided by the learning environment. They may have cognitive adjustment to the assessment of selfefficacy. Then, it would affect their learning motivation. Therefore, based on the concept of self-efficacy, this study 
validates its mediating effect between classroom climate and learning motivation.

\section{THEORETICAL BACKGROUND AND HYPOTHESES}

\section{A. The Impact of Classroom Climate on Learning Motivation}

In relevant studies on the motivation, intrinsic motivation and extrinsic motivation are the two motivated types widely described and discussed by scholars. They would guide the direction, intensity and persistence of individual behavior (Ryan \& Deci, 2000). Also, they are key factors to get academic success at all stages of their education $(\mathrm{Ng} \& \mathrm{Ng}$, 2015). Intrinsic motivation of the learning usually refers to the fun, happiness and satisfaction that individuals can obtain when they engage in learning activities. The extrinsic motivation of learning focuses on goal-driven factors, such as the reward and benefits of learning outcomes. Motivation objective orientation of learning may be internal or extrinsic based on the individuals' different perception of rewards. For example, some students' learning motivation is self-directed, including the learning needs and interest, ideals, proper pride, self-realization, etc. The intrinsic desires are dominant. The individuals would set and choose goals. In addition, some of the learning motivations are others-oriented. The individuals pursue academic achievements to meet the goals, expectations and approvals of important people such as the community, families, and teachers. And then, they want to earn honorary title and scholarship. Then, they would get enviable career or social relationship. Intrinsic motivation is associated with high-level effort and mission performance, as well as with the preference for the challenge (Patall, Cooper, \& Robinson, 2008). The external learning motivation is influenced by external triggers. When the external inducement changes, the intensity of the motivation may also change, which has stronger directivity and greater variability than that of the intrinsic learning motivation. If we can't have the adjustment timely and effectively, the performance of learning may be affected. Also, it would affect the learning effect.

It can be said that learning motivation is a dynamic concept and a holistic system composed of various motivating factors. Apart from personal factors, classroom climate is an important situational factor that influences personal motivation. Classroom climate is also known as the learning environment (Adelman \& Taylor, 2005). The components encompass the physical environment (eg, space, facilities) and the interactions among the members of the class (Shafritz, Koeppe \& Scoper, 1995). Such interactive influences gradually form the common psychological traits or tendencies of class members. And it creates a unique atmosphere different from that of other classes that affects the concept and behavior of each member.

Studies on motivation theory and learning point out that learning environment factors would affect the learning motivation of individuals. And learning environment factors include teachers' teaching strategies, class activities, the interaction between students and teachers, and the interaction between students and students (eg, Brophy, 1998). Hanrahan
(1998) also pointed out that the teaching of teachers and the relationship between teachers and students will affect the motivation of students. From the above discussion, teachers and students play an important role in learning motivation (Heitzmann, 2009). Donitsa-Schmidt \& Shohamy (2001) argue that teachers' teaching beliefs and behaviors play a decisive role in the formation of student motivation. Ladd (1990) also points out those students who can be accepted by their peers are more successful in learning. Goodenow (1993) considers that a supportive peer group would be conducive to the learning. On the other hand, Slavin (1995) points out the enjoyment of cooperative activities should enhance students' motivation from the perspective of cooperative learning. The results of Tuan \& Chin (2000) also show that the supportive learning environment created by the students is very important.

To sum up, this research suggests that it is very important to create a positive and cooperative classroom climate through the efforts of teachers and students. It would be conducive to the effective learning. When the individual student can't fully feel the support and encouragement of teachers and their peers in the learning process, it would reduce the learning motivation due to the shortage of cooperation and trust. When the teachers give positive feedback or encouragement to the peers timely, they would create learning atmosphere of respect, cooperation and support. And it will enhance students' learning motivation. Accordingly, this study proposes the following assumptions to be validated.

H1: Teacher support has significant and positive effect on learning motivation.

H1a: Teacher support has significantly positive effect on the motivation of learning interest.

H1b: Teacher support has significant and positive effect on the motivation of career progression.

H1c: Teacher support has significant and positive effect on the motivation of self-development.

H1d: Teacher support has significant and positive effect on the motivation of social relationships.

H1e: Teacher support has significant and positive impact on the motivation of external expectation.

$\mathrm{H} 2$ : The relationship among students has significant and positive effect on learning motivation.

H2a: The relationship among students has significant and positive effect on the motivation of learning interest.

$\mathrm{H} 2 \mathrm{~b}$ : The relationship among students has significant and positive effect on the motivation of career progression.

$\mathrm{H} 2 \mathrm{c}$ : The relationship among students has significant and positive effect on the motivation of self-development.

$\mathrm{H} 2 \mathrm{~d}$ : The relationship among students has significant and positive effect on the motivation of social relations.

$\mathrm{H} 2 \mathrm{e}$ : The relationship among students has significant and positive effect on the motivation of external expectation. 


\section{B. The Mediating Effect of Self-efficacy in the Relationship between Classroom Climate and Learning Motivation}

Social learning theory argues that individuals have a selfregulation mechanism. And perceived self-efficacy is the central factor of self-regulation (Bandura, 1982). Selfefficacy refers to the individual's subjective evaluation on his or her ability to perform certain tasks. And learning selfefficacy refers to the concept of self-efficacy in the learning. And people can achieve certain level of subjective faith in his study. Students' subjective evaluation on the expected performance and academic learning ability would affect one's learning motivation and behavior (e.g., Busch, 1995)

There are four main sources of self-efficacy (Taggar \& Seijts, 2003). First, the experience of success is the most important factor affecting self-efficacy. And self-efficacy is built upon constant success. It would enhance one's awareness of self-efficacy. Conversely, repeated failure experience will reduce self-efficacy. Second, it is vicarious learning. The students would establish perceived selfefficacy from observing the successful behaviors of others. When observing other people's failure with high efforts, they would reduce the evaluation on the ability. Also, they would reduce the efforts. Third, it is social or verbal persuasion. The important people should give positive feedback or encouragement to the individuals. And they should persuade the individuals to believe that they have the ability to pursue their goals. The individuals are more willing to face difficulties and improve self-efficacy. If the individuals don't trust in the persuader, it may reduce self-efficacy. Fourth, it is physiological or psychological arousal. The messages generated by emotion and physical agitation can affect the judgment of self-efficacy. Sometimes, according to physical and emotional states, people would make evaluation on their abilities. When individuals are anxious, they often give rise to doubts about their abilities. In the face of fear caused by the emotion, they would usually reduce the performance. And it would affect self-efficacy. The above four factors would affect self-efficacy. And the individuals' cognitive assessment and integration of these four sources would finally determine self-efficacy (Bandura, 1982), which can be used to judge personal efficacy.

In this paper, if teachers can provide successful guidance and support in the learning process, the students should be able to strengthen their self-evaluation. And then, it would achieve their learning goals. It would improve the learning motivation. Second, students with poor learning performance can also build confidence that they can follow similar behaviors from the successful performance of their peers under the good learning interaction with their classmates. The students would reduce the chances of directly facing the failure and improve perceived self-efficacy. And then, it would improve the learning motivation. In addition, if the teachers often give positive feedback or encouragement to the students, the students would believe that they have ability to achieve their learning goals. And these students are willing to overcome the learning obstacles. It is also helpful to build perceived self-efficacy. Thereby, it could enhance the learning motivation. Furthermore, if teachers and students can support each other and help each other, they could reduce the negative emotions or physical phenomena of learning. They could maintain their self-efficacy and improve the learning motivation. In summary, the author proposes the following assumptions to be validated.

H3: Self-efficacy has mediating effect on the relationship between teacher support and learning motivation.

H3a: Self-efficacy has mediating effect on the motivation of learning interest and teacher support.

H3b: Self-efficacy has mediating effect on the motivation of career progression and teacher support.

H3c: Self-efficacy has mediating effect on the motivation of self-development and teacher support.

H3d: Self-efficacy has mediating effect on the motivation of social relationships and teacher support.

H3e: Self-efficacy has mediating effect on the motivation of external expectation and teacher support.

H4: Self-efficacy has mediating effect on the relationship among students and learning motivation.

H4a: Self-efficacy has mediating effect on the relationship among students and the motivation of learning interest.

H4b: Self-efficacy has mediating effect on the relationship among students and the motivation of career progression.

H4c: Self-efficacy has mediating effect on the relationship among students and the motivation of selfdevelopment.

H4d: Self-efficacy has mediating effect on the relationship among students and the motivation of social relationship.

H4e: Self-efficacy has mediating effect on the relationship among students and the motivation of external expectation.

\section{METHOD}

\section{A. Sample and Procedures}

A total of 250 questionnaires were sent out to students of public administration in the college of business in B University. 216 questionnaires were collected. The recovery rate was $86.4 \%$, excluding 8 invalid questionnaires. And there were 208 valid questionnaires. The effective recovery rate was $83.2 \%$. The tested samples include many female students, accounting for $74 \%$ of the total. There are many students in the third grade, accounting for $40.4 \%$. It is followed by the students in second grade, accounting for $34.6 \%$.

\section{B. Measures}

Classroom climate is based on a scale developed by Huang Mingyu (2004), which is divided into two dimensions. First, it is the relationship among students. It refers to the status and attitude of cooperative learning among classmates 
in learning environment of the class. It has 6 questions $(\alpha=$ 0.79). Second, it is teacher support. It refers to the teacher's attitude towards the students' learning. It has a total of 9 questions $(\alpha=0.89)$.

The scale of learning motivation is based on the scale compiled by Liao Zhisheng (2004). There are five dimensions. First, it refers to the learning interest. In order to participate in learning, have cognitive interest and academic progress, the students should have the learning. And it has a total of 5 questions $(\alpha=0.83)$. Second, it refers to selfdevelopment. The students pursue personal development, adaptation and self-understanding. They would participate in learning. It has a total of 6 questions $(\alpha=0.84)$. Third, it refers to the social relations. The learners participated in the study for the purpose of seeking comfort, having friends with their classmates and being accepted by their classmates. It is conducive to social contacts and interpersonal interactions. And it has a total of 5 questions $(\alpha=0.84)$. Fourth, it refers to external expectation. In order obey the important people; they would participate in the study. Then, they would have the progress. It has a total of 6 questions $(\alpha=0.72)$.

The scale of learning efficacy uses a scale developed by Jex $\&$ Bliese (1999). It has a total of 5 questions $(\alpha=0.81)$.

At the same time, in order to make the results of this study more stable, this study takes "gender" and "grade" as the control variables.

\section{Analysis}

In this study, the effect of classroom climate on learning motivation ( $\mathrm{H} 1$ and $\mathrm{H} 2)$ was verified by multiple regressions. And with the hierarchical regression, it could analyze the mediating effect of self-efficacy on the relationship between class climate and learning motivation (H3 and $\mathrm{H} 4)$.

In addition, the students would answer all questionnaires in this study. With Hannan's one-factor test (Podsakfoff, MacKenzie, Lee, \& Podsakfoff, 2003), it is possible to detect whether it could generate common method variance. In this study, the author makes the factor analysis with all the items. There were 9 factors that could be extracted without rotation, of which no comprehensive factor was included. The first factor explained only $18.9 \%$ of the variance. Therefore, there is no serious problem of common method variance.

\section{RESULTS}

First of all, the correlation analysis was carried out in this study. The results in "Table I" show that there is a significant positive correlation among all the variables in this study (.27.54). Then, in the direct influence of the relationship between classroom climate and learning motivation, the results of multiple regression analysis in "Table 2" show that teachers' support and classmates' relationships have significant and positive impact on seeking knowledge $(\beta=.32, \mathrm{p}<.001 ; \beta$ $=.22, \mathrm{p}<.01)$, career progression $(\beta=.29, \mathrm{p}<.01 ; \beta=.25, \mathrm{p}$ $<.01)$, self-development $(\beta=.19, \mathrm{p}<.05 ; \beta=.19, \mathrm{p}<.05)$, Social relationships $(\beta=.32, \mathrm{p}<.001 ; \beta=.25, \mathrm{p}<.01)$, external expectations $(\beta=.19, \mathrm{p}<.05 ; \beta=.17, \mathrm{p}<.05)$, and other learning motivation. Therefore, the author supposes that $1 \mathrm{a}-1 \mathrm{e}$ and $2 \mathrm{a}-2 \mathrm{e}$ are supported.

TABLE I. HIERARCHICAL REGRESSION ANALYSIS OF SELF-EFFICACY ON CLASSROOM CLIMATE AND LEARNING Motivation

\begin{tabular}{|c|l|l|l|l|l|l|l|l|l|l|l|}
\hline Variable & Mean & $\begin{array}{l}\text { standard } \\
\text { deviation }\end{array}$ & 1 & 2 & 3 & 4 & 5 & 6 & 7 & 8 & 9 \\
\hline gender & 1.74 & .44 & - & & & & & & & & \\
\hline grade & 2.15 & .79 & $.14^{*}$ & - & & & & & & & \\
\hline $\begin{array}{c}\text { relationship } \\
\text { among the } \\
\text { classmates }\end{array}$ & 3.18 & .57 & -.08 & $-.27^{* *}$ & - & & & & & & \\
\hline $\begin{array}{c}\text { teacher } \\
\text { support }\end{array}$ & 3.55 & .60 & .01 & $-.29^{* *}$ & $.56^{* *}$ & - & & & & & \\
\hline $\begin{array}{c}\text { learning } \\
\text { interest }\end{array}$ & 3.73 & .65 & .06 & -.07 & $.37^{* *}$ & $.38^{* *}$ & $(.83)$ & & & & \\
\hline $\begin{array}{c}\text { self- } \\
\text { development }\end{array}$ & 3.77 & .63 & -.00 & -.06 & $.28^{* *}$ & $.29^{* *}$ & $.54^{* *}$ & $(.84)$ & & & \\
\hline $\begin{array}{c}\text { social } \\
\text { relationship }\end{array}$ & 3.81 & .63 & -.01 & $-.17^{*}$ & $.42^{* *}$ & $.47^{* *}$ & $.48^{* *}$ & $.52^{* *}$ & $(.84)$ & & \\
\hline $\begin{array}{c}\text { external } \\
\text { expectation }\end{array}$ & 3.46 & .57 & .00 & -.00 & $.29^{* *}$ & $.32^{* *}$ & $.31^{* *}$ & $.26^{* *}$ & $.38^{* *}$ & $(.72)$ & \\
\hline self-efficacy & 3.32 & .63 & -.04 & -.08 & $.43^{* *}$ & $.34^{* *}$ & $.46^{* *}$ & $.44^{* *}$ & $.47^{* *}$ & $.39^{* * *}$ & $(.81)$ \\
\hline
\end{tabular}

Then, based on Baron \& Kenny's (1986) mediation effect, we could recognize conditions. This study examines sequentially whether the mediation conditions of selfefficacy are valid. First, the above results have shown that classroom climate and learning motivations have significant and positive impact. Second, model 6 in "Table I" shows that self-efficacy of teacher support and the relationship among students have significant and positive effects respectively $(\beta$
$=.38, \mathrm{p}<.001 ; \beta=.19, \mathrm{p}<.05)$. Third, from the model $1-4$, $2-4,3-4,4-4$, and 5-4 in "Table I", we can see that the selfefficacy has significant and positive impact on learning interest $(\beta=.47, p<.001) \beta=.35, p<.001)$, selfdevelopment $(\beta=.44, p<.001)$, social relationships $(\beta=.47$, $\mathrm{p}<.001)$, external expectations $(\beta=.36, \mathrm{p}<.001)$ and other learning motivations. 
We should confirm the above prerequisites to verify the mediation effect. And then, we could verify the mediating effect of self-efficacy between classroom climate and learning motivation. The comparison of model 1-2 and model 1-3 in "Table II" shows that the regression coefficients of students' relationships in learning interest isn't obvious in model $1-3(\mathrm{p}=.00 \rightarrow \mathrm{p}=.09)$. The regression coefficients of teachers' support in learning interest increase slightly. And it is still significant $(\mathrm{p}=.006 \rightarrow \mathrm{p}=.007)$. After comparing model 2-2 with model 2-3, it can be seen that the regression coefficient of classmate relationship on career progression increases slightly. And it is significant with the introduction of self-efficacy in model $2-3(\mathrm{p}=.00 \rightarrow \mathrm{p}=.02)$. The regression coefficients supported by teachers isn't obvious $(\mathrm{p}=.04 \rightarrow \mathrm{p}=.12)$. Comparing model 3-2 with model 3-3, it shows the regression coefficient of classmates' relationship on self-development isn't significant in model 33 with the introduction of self-efficacy $(p=.03 \rightarrow p=.81)$. The regression coefficient of teacher support on self- development is slightly improved. And it is still significant $(\mathrm{p}=.018 \rightarrow \mathrm{p}=.022)$. Comparing model $4-2$ with model $4-3$, it shows that the regression coefficient of classmate relationship on social relationship isn't significant in model 4-3 with the introduction of self-efficacy $(\mathrm{p}=.000 \rightarrow$ $\mathrm{p}=.054)$. The coefficient of regression of teacher support on social relations increases slightly. And it is significant $(\mathrm{p}=.000 \rightarrow \mathrm{p}=.001)$. Finally, comparing model 5-2 and model 5-3, it shows that the regression coefficient of students' expectation on external expectation isn't significant $(\mathrm{p}=.002 \rightarrow \mathrm{p}=.373)$. The regression coefficient of teachers' support on external expectation increases slightly. However, it is significant $(\mathrm{p}=.025 \rightarrow \mathrm{p}=.033)$.

Then, the study further confirms whether the indirect effect of self-efficacy is significant with Sobel test (Sobel, 1982). The test results show that there is significant indirect effect of self-efficacy on the relationship among classmate relationship, teacher support and learning motivation $(\mathrm{z}>$ $1.96, \mathrm{p}<.001)$. Therefore, $\mathrm{H} 3$ and $\mathrm{H} 4$ are valid.

TABLE II. REGRESSION ANALYSIS OF THE RELATIONSHIP AMONG VARIABLES IN THIS STUDY

\begin{tabular}{|c|c|c|c|c|c|c|c|c|c|c|c|c|c|c|c|c|c|}
\hline \multirow{3}{*}{$\begin{array}{c}\underset{\boldsymbol{D V} \rightarrow}{\boldsymbol{\beta}(\mathbf{p})} \\
\text { IV }\end{array}$} & \multicolumn{16}{|c|}{ learning motivation } & \multirow{3}{*}{$\begin{array}{c}\begin{array}{c}\text { self- } \\
\text { efficacy }\end{array} \\
\begin{array}{c}\text { Model } \\
6\end{array}\end{array}$} \\
\hline & \multicolumn{4}{|c|}{ learning interest } & \multicolumn{4}{|c|}{ self-development } & \multicolumn{4}{|c|}{ social relationship } & \multicolumn{4}{|c|}{ external expectation } & \\
\hline & $\begin{array}{c}\text { Model } \\
1-1\end{array}$ & $\begin{array}{c}\text { Model } \\
1-2\end{array}$ & $\begin{array}{c}\text { Model } \\
1-3\end{array}$ & $\begin{array}{c}\text { Model } \\
1-4\end{array}$ & $\begin{array}{c}\text { Model } \\
3-1\end{array}$ & $\begin{array}{c}\text { Model } \\
3-2\end{array}$ & $\begin{array}{c}\text { Model } \\
3-3\end{array}$ & $\begin{array}{c}\text { Model } \\
3-4\end{array}$ & $\begin{array}{c}\text { Model } \\
4-1\end{array}$ & $\begin{array}{c}\text { Model } \\
4-2\end{array}$ & $\begin{array}{c}\text { Model } \\
4-3\end{array}$ & $\begin{array}{c}\text { Model } \\
4-4\end{array}$ & $\begin{array}{c}\text { Model } \\
5-1\end{array}$ & $\begin{array}{c}\text { Model } \\
5-2\end{array}$ & $\begin{array}{c}\text { Model } \\
5-3\end{array}$ & $\begin{array}{c}\text { Model } \\
5-4\end{array}$ & \\
\hline constant & $3.66^{* * *}$ & $1.63^{* * *}$ & $1.01^{* *}$ & $2.16^{* * *}$ & $3.83^{* * *}$ & $2.38^{* \cdots *}$ & $1.78^{\ldots+*}$ & $2.31^{* * *}$ & $4.07^{+\cdots+}$ & $1.89^{* \cdots *}$ & $1.31^{*+*}$ & $2.23^{* \cdots *}$ & $3.44^{\cdots \cdots}$ & $2.10^{+* * *}$ & $1.68^{* * * *}$ & $2.29^{\cdots * *}$ & $1.39^{* * *}$ \\
\hline gender & .12 & .12 & .13 & & .04 & .04 & .05 & & .02 & .02 & .02 & & .03 & .03 & .04 & & -.03 \\
\hline grade & -.07 & .04 & .03 & & -.06 & .03 & .01 & & $-.14^{* *}$ & -.02 & -.03 & & -.02 & .06 & .05 & & .05 \\
\hline $\begin{array}{c}\text { classmate } \\
\text { relationship }\end{array}$ & & $.32^{2 * \cdots}$ & .15 & & & $.19^{*}$ & .02 & & & $.32^{\cdots \cdots+}$ & .16 & & & $.19^{*}$ & .07 & & $.38^{\cdots+\cdots}$ \\
\hline $\begin{array}{l}\text { teacher } \\
\text { support }\end{array}$ & & $.22^{* *}$ & $.01^{* *}$ & & & $.19^{*}$ & $.17^{*}$ & & & $.25^{* \prime}$ & $.24^{* \prime}$ & & & $.17^{*}$ & $.15^{*}$ & & $.19^{\circ}$ \\
\hline self-efficacy & & & $.38^{* * *}$ & $.47^{\cdots \cdots}$ & & & $.36^{\cdots *}$ & $.44^{* *}$ & & & $.35^{* *+}$ & $.47^{\cdots *}$ & & & $.25^{* *}$ & .36 & \\
\hline $\mathbf{F}$ & 1.21 & $10.71^{\cdots * *}$ & $15.74^{\ldots+\cdots}$ & $54.53^{* *}$ & .53 & $5.17^{\circ}$ & $10.27^{\cdots \cdots+}$ & $48.79^{m+*}$ & 2.86 & $14.23^{\ldots+\cdots}$ & $18.71^{* * *}$ & $57.61^{\cdots *}$ & .11 & $5.17^{* *}$ & $7.42^{\cdots+*}$ & $37.61^{+*}$ & $12.4^{7+\cdots}$ \\
\hline $\mathbf{R}^{2}$ & .01 & .18 & .29 & .21 & .01 & .10 & .21 & .19 & .03 & .22 & .32 & .22 & .00 & .10 & .16 & .15 & .20 \\
\hline$\Delta R^{2}$ & & .17 & .11 & & & .09 & .11 & & & .19 & .10 & & & .10 & .06 & & \\
\hline
\end{tabular}

\section{CONCLUSION}

The main purpose of this study is to explore the relationship between classroom climate and learning motivation of college students, and to verify the mediating effect of self-efficacy on the relationship between classroom climate and learning motivation. The results show that students' relationship and teacher support have significant and positive effect on learning interest, self-development, social relations and external expectations. The self-efficacy has mediating effect on classroom climate and learning motivation. According to the results of this study, when students have good relationships and teachers show highlevel earnestness and support for students' learning, the students can build perceived self-efficacy. It enables students to achieve their learning goals. Thereby, it could improve the learning motivation. The students would participate in learning. Also, they would pursue personal development. They can make friends with classmates. They would obey important people to make progress in different orientations. At the same time, the good relationship among the students would have cognitive impact on perceived self-efficacy. And then, it would affect the learning motivation. It is more effective than that of teacher support. And it may be related to the interaction of learning with peers.

\section{A. Study Limitation}

The results of this study are subject to a few limitations. First, the subject of this study is limited to students majoring in management of public utilities of the colleges of business in B University. And the results may be applied the students of that major. Therefore, it has great limitation in external validity. Second, during the data collection process, some students may hold a defensive attitude when answering certain questions. Therefore, any replies on the questionnaire may result in the error of analysis results in this study. 


\section{B. Practical Implications and Future Research}

First of all, viewing from the students' opinions, individual learning can build up good interaction with likeminded students and increase their confidence in achieving their learning goals. From the perspective of the teachers, teachers should actively understand the characteristics, competence levels and differences of learning styles of individual students. They can help the students establish clear learning objectives. And then, the students could gain successful experience in learning. The students would enhance their learning interest and the learning motivation.

Secondly, classroom teaching content should be adjusted in time. According to various ways, the teachers should give positive feedback or encouragement to students after class. And the teachers should persuade them to believe that they have the ability to achieve their goals through their own efforts. Furthermore, the teachers should encourage students to organize various learning teams, participate in discussions and activities, promote mutual communication and opportunities between teachers and students, and learn from each other. The students can learn together, make influences on each other and have the progress together. The students can observe the successful performance of other students. And they can establish their own confidence in learning performance. In subtle process, it would promote the effect of group learning. It would facilitate the construction of learning atmosphere with positive energy. Thereby, it would enhance the learning efficiency of students.

Finally, future research can add other situational variables such as teacher's teaching strategies and class cohesion. Through cross-level research and design, the statistical analysis and inference of the influence relationships among different levels of variables are more accurate. The universities can conduct a comparative analysis with other university students who are specialized in the same field. They can establish the validity of the research in this aspect as well as understand the problems and differences.

\section{REFERENCES}

[1] G. Denzine, , and R. Brown, "Motivation to learn and achievement," in Media Rich Instruction: Connecting Curriculum to All Learners, Springer International Publishing, 2014, pp. 19-34.

[2] K. Hakan, E. Munire, "Academic motivation: gender, domain and grade differences," Social and Behavioral Sciences, vol. 143, pp.708 $-715,2014$.

[3] J. Brophy, "Motivating students to learn," Madison, WI, McGraw Hill, 1998.

[4] P.R. Pintrich and D.H. Schunk, "Motivation in education: theory, research and applications," Englewood Cliffs, NJ: Prentice Hall, 1996.

[5] G. Djigic and S. Stojiljkovic, "Classroom management styles, classroom climate and school achievement," Social and Behavioral Science, vol. 29, pp. 819-828, 2011,

[6] H.S. , Adelman and L. Taylor, "Classroom Climate. in Encyclopedia of School Psychology, S.W. Lee, P.A. Lowe, and E. Robinson, Eds. Thousand Oaks, CA: Sage, 2005.

[7] A. Bandura, "Self-efficacy mechanism in human agency," American Psychologist, vol. 37, pp. 122-147, 1982.
[8] G. Torkzadeh and T.P. Van Dyke, "Development and validation of an Internet self-efficacy scale,” Behavior \& Information Technology, vol. 20, pp. 275-280, 2001.

[9] R.M. Ryan and E.L. Deci, "Intrinsic and extrinsic motivations: classic definitions and new directions," Contemporary Educational Psychology, vol.25, pp. 54-67, 2000.

[10] C. F. Ng and P. K. Ng, 2015. "A Review of Intrinsic and Extrinsic Motivations of ESL Learners," International Journal of Languages, Literature and Linguistics, vol. 1, pp. 98-105.

[11] E.A. Patall, H. Cooper, and J.C. Robinson. "The effects of choice on intrinsic motivation and related outcomes: a meta-analysis of research findings," Psychological Bulletin, vol. 134, pp. 270-300, 2008.

[12] J. Shafritz, R. Koeppe, and E. Scoper, "The facts on file dictionary of education," New York: Facts On File, 1995.

[13] J. Heitzmann, "The influence of the classroom climate on students' motivation," in: UPRT 2008: Empirical studies in English applied linguistics," R. Lugossy, J. Horváth, and M. Nikolov, Eds. Pécs: Lingua Franca Csoport, 2009, pp. 207-224.

[14] S. Donitsa-Schmidt, O. Inbar, and E. Shohamy, "The effects of teaching spoken Arabic on student's attitudes and motivation in Israel,” The Modern Language Journal, vol. 88, pp. 217-228, 2004.

[15] C. Goodenow, "Classroom belongings among early adolescent students: relationships to motivation and achievement," Journal of Early Adolescence, vol. 13, pp. 21-43, 1993.

[16] R.E. Slavin, Cooperative learning: theory, research, and practice, 2nd Ed. Boston: Allyn \& Bacon, 1995.

[17] H.L. Tuan and C.C. Chin, "Promoting junior high school students' motivation toward physical science learning (III)," Report for National Research Council (NSC 89-2511- S018-030), 2000.

[18] T. Busch, "Gender differences in self-efficacy and attitudes toward computers, "Journal of Educational Computing Research, vol. 12, pp 147-158, 1995.

[19] S. Taggar, and G.H. Seiijts, "Leader and staff role-efficacy as antecedents of collective-efficacy and team performance," Human Performance, vol. 16, pp. 131-156, 2003.

[20] M.Y. Huang, "Research of relationship among self-directed learning readiness, classroom climate and learning satisfaction of adult learners," unpublished master's thesis, Graduate Institute of Adult Education, National Kaohsiung Normal University, Taiwan, 2004.

[21] J.S. Laio, "A study on the relationship between learning motivation and learning satisfaction of postgraduate," unpublished master's thesis, National Pingtung University, Taiwan, 2003.

[22] S.M. Jex and P.D. Bliese, "Efficacy beliefs as a moderator of the impact of work related stressors: a multilevel study," Journal of Applied Psychology, vol. 84,pp. 349-361, 1999.

[23] P.M. Podsakfoff, S.B. MacKenzie, J.Y. Lee, and N.P. Podsakfoff, "Common method biases in behavioral research: a critical review of the literature and recommended remedies," Journal of Applied Psychology, vol. 88, pp. 879-903,2003.

[24] M.E. Sobel, "Asymptotic confidence intervals for indirect effects in structural equation methods," in Sociological Methodology, S. Leinhardt, Ed. Washington DC: American Sociological Association, 1982 , pp. $290-312$. 